Canadian University Music Review

Canadian University Music Review

Revue de musique des universités canadiennes

\title{
Some Motets in Honour of St Joseph in the Archives of the Ursulines of Québec
}

\section{Erich Schwandt}

Volume 17, numéro 1, 1996

URI : https://id.erudit.org/iderudit/1014693ar

DOI : https://doi.org/10.7202/1014693ar

Aller au sommaire du numéro

\section{Éditeur(s)}

Canadian University Music Society / Société de musique des universités canadiennes

\section{ISSN}

0710-0353 (imprimé)

2291-2436 (numérique)

Découvrir la revue

\section{Citer cet article}

Schwandt, E. (1996). Some Motets in Honour of St Joseph in the Archives of the Ursulines of Québec. Canadian University Music Review / Revue de musique des universités canadiennes, 17(1), 57-71. https://doi.org/10.7202/1014693ar

\section{Résumé de l'article}

There is a handful of motets in honour of one of New France's most important patrons-St Joseph-preserved at the Archives of the Ursulines of Québec. This group of eight motets has formed the basis of speculation about the musical gifts of Père René Ménard and Mère Marie de St Joseph. Both of them are mentioned in 1640 as being capable musicians, but both were dead by the middle of the seventeenth century. In this article the St Joseph motets are examined to see if there is any basis for connecting any of the music to either person. Unfortunately, all of the music is stylistically much too late to have been composed by Père Ménard, or to have been assembled or copied by Mère de St Joseph. Solum nomen super est.
All Rights Reserved @ Canadian University Music Society / Société de musique des universités canadiennes, 1996
Ce document est protégé par la loi sur le droit d'auteur. L'utilisation des services d'Érudit (y compris la reproduction) est assujettie à sa politique d'utilisation que vous pouvez consulter en ligne.

https://apropos.erudit.org/fr/usagers/politique-dutilisation/ 


\section{SOME MOTETS IN HONOUR OF ST JOSEPH IN THE ARCHIVES OF THE URSULINES OF QUÉBEC}

\section{Erich Schwandt}

The object of this essay is to examine a group of eight seventeenth- and eighteenth-century motets in honour of St Joseph in some detail, to consider their place, if any, in the liturgy, and to determine their chronology. ${ }^{1}$ The eight pieces are preserved at the Archives of the Ursulines of Québec. The manuscripts from which they come are described fully in my thematic catalogue of sacred figural music in New France, ${ }^{2}$ and I will be using the numbering of manuscripts and pieces set out there.

St Joseph was officially named Patron of Canada in 1624, and St Joseph and the Holy Family occupy a prominent place in the history of New France. The Ursulines arrived in Canada to build their Monastery and establish their school for girls in 1639, and St Joseph seems to have played a major rôle in the affair. The Venerable Marie Guyart de l'Incarnation, the founder and first superior of the Ursulines of Québec, vowed to build a house for Jesus, Mary, and Joseph in Canada already in the early 1630s. The sponsor-Madame de la Peltrie, who had also made a vow to St Joseph to establish an Ursuline Monastery in Canada-accompanied the three original Ursulines to Canada, and paid for everything. A third woman, Mère Marie de Savonnières de St Bernard, one of the founders of the Québec Monastery, vowed to St Joseph that if she were chosen to accompany Marie de l'Incarnation to the new world, she would change her name in religion to Marie de St Joseph. ${ }^{3}$

One of the most striking instances of devotion to St Joseph and the Holy Family occurred in 1690. In the fall of that year, when Québec was under siege, the Ursulines' painting of the Holy Family was hung on the cathedral tower to protect the city, and the British, commanded by William Phipps, were defeated. ${ }^{4}$ St Joseph and the Holy Family are also important in the history of music in New France: the plainchant propers assembled in Québec for the Feast of the Holy

1 A shorter version of this article was presented at the annual meeting of the Canadian University Music Society at the University of Calgary in 1994. This article is dedicated to the memory of Mère Marcelle Boucher, the late archivist of the Monastery of the Ursulines of Québec. I would like to thank Sœur Michelle Leblanc, o.s.u., president of the board of the Ursulines of Québec for permission to publish material from their archives.

2Erich Schwandt, "The Motet in New France: Some 17th- and 18th-century Manuscripts in Québec," Fontes Artis Musicae 28, no. 3 (1981): 194-219.

3 This account of vows to St Joseph has been gleaned from Les Ursulines de Québec depuis leur établissement jusqu'à nos jours, 2nd ed., vol. 1 (Québec: Darveau, 1878), 1-16.

4 Ibid., 440-43. 
Family in the last third of the seventeenth century are discussed at length in every book that deals with music in Canada. ${ }^{5}$ There is another body of music associated with St Joseph that has never been examined critically: the eight motets under consideration here. I did not include any of them in my anthology because of the musical difficulties the pieces present. ${ }^{6}$ Of the eight motets, two (numbers 36 and 37 of my thematic catalogue) are incomplete, for a leaf of the manuscript has gone missing; another (number 38) has irregular notation and no barlines; and another (number 108) seems to be only one voice of what must originally have been a two-voice piece. Thus, only four of the St Joseph motets can be studied as complete pieces. I have now made reconstructions of the four problematic pieces, and these, as well as the others are included in my new anthology. ${ }^{7}$

Two important figures in the history of music in New France have been intimately associated with the St Joseph repertoire by Willy Amtmann: ${ }^{8}$ Père René Ménard (1605-1661) is mentioned once in a letter dating from 1640 as a composer of motets, ${ }^{9}$ and this one tantalizing reference has led to a good deal of speculation about his activities as a composer active in New France. He has even been named, albeit tentatively, as the composer of some of the pieces under discussion here: Amtmann names him as the composer of number 76, "O Joseph, sponse virgo," and this information appears in the Encyclopedia of Music in Canada.

Mère Marie de Savonnières de St Joseph (1616-1652) is another shadowy figure in the history of music in New France. We know that she was a musician: she sang well, played the viola da gamba, and taught music to her little students in Québec. There, it seems to me, the trail ends. She died in 1652 at the age of thirty-six, and the subsequent fires at the Monastery have apparently removed all traces of her musical accomplishments: her name alone remains to us. ${ }^{10}$ Nonetheless, Amtmann has made her the alleged copyist of a manuscript volume of motets. ${ }^{11}$ Timothy McGee, relying on Amtmann's account, further embellishes the story of Mère de St Joseph:

It is possible that some of the anonymous works in the collection [of music at the Ursulines] were composed by members of the clergy living in Québec. There is no record of the date of acquisition of this material, but from what is known about the activities and background of Mother Marie de St Joseph, we

\footnotetext{
5The clearest account is given by Helmut Kallmann, A History of Music in Canada (Toronto: University of Toronto Press, 1960), 22-33.

6The Motet in New France: Twenty Motets, Antiphons, and Canticles from the Archives of the Ursulines and the Archives of the Hôtel-Dieu of Québec, transcribed and edited by Erich Schwandt (Victoria: Éditions Jeu, 1981).

7 The Motet in New France, Part II, transcribed and edited by Erich Schwandt (Victoria: Éditions Jeu, 1994).

8Willy Amtmann, Music in Canada, 1600-1800 (Montréal: Habitex Books, 1975), 77-78.

9 The Letter from Mère Anne de Ste Claire to the Ursulines of Paris (dated 2 September 1640) is printed in Les Ursulines de Québec, vol. 1, 39-41.

10Kallmann, 16-17.

11 Amtmann, 77-78.
} 
can assume that some of the music was assembled for performance during her years as music teacher (1639-1652). ${ }^{12}$

The volume of motets that Amtmann cites is designated as Motets 1 in my thematic catalogue. The datable pieces, all adapted for use in New France, are shown in Table I. Because the fourth entry in Motets 1 is a motet from Campra's fifth book (1720), the volume cannot have been copied earlier than that. Clearly, Mère de St Joseph can have had no hand in assembling or copying it. Whether Père Ménard composed any of the eight pieces under consideration here remains to be seen.

\section{Table I. Pieces adapted for use in New France}

Les Ursulines de Québec: Cantiques (C Qur: $C$ )

\begin{tabular}{lll} 
Number & Composer & Work or Collection \\
\hline 1 & Desmarets & Didon, 1693 \\
2 & Gastoldi & Amphion Sacré, 1615 \\
3 & Campra & L'Europe Galante, 1697 \\
4 & Anonymous & Recueil d'Airs, 1706 \\
5 & Lully & Atys, 1689 \\
10 & Campra & Motets I, 1695 \\
52 & Du Mont & Cantica Sacra, 1652/62
\end{tabular}

Les Ursulines de Québec: Motets 1 (C Qur: M1)

\begin{tabular}{lll} 
Number & Composer & Work or Collection \\
\hline 58 & Campra & Motets V, 1720 \\
64 & Bernier & Mottets I, 1703 \\
67 & Campra & Motets I, 1695 \\
68 & ?Destouches? & ?Concert Spirituel, 1736? \\
69 & Delalande & Motets XVII, 1729-1733 \\
70 & Campra & Motets I, 1695 \\
86 & Bernier & Mottets I, 1703 \\
99 & Bernier & Mottets I, 1703 \\
104 & Bernier & Mottets I, 1703 \\
112 & Morin & Motets I, 1704
\end{tabular}

Hôtel-Dieu de Québec (C Qhd)

\begin{tabular}{lll} 
Number & Composer & Work or Collection \\
\hline 119 & Lefébvre & Concert Spirituel, 1755 \\
122 & Brossard & Élevations, 1699
\end{tabular}

The St Joseph motets have a common theme: praise, honour, and devotion to St Joseph; and they all speak of St Joseph in his rôle as the head of the Holy Family. He is praised as the chaste spouse of Mary and the nurturing fosterfather of Christ. These devotional pieces were undoubtedly sung to honour St Joseph throughout the year. Motets 35-38 form a unified group; indeed, they 
seem to have been copied as a set. (The missing leaf, numbered xxi-xxii, probably contained another motet-very likely in honour of St Joseph.) These four motets seem to date from the late seventeenth century: they are conceived modally, and their melodies are very well made.

No. 35 (C xix-xx) Motet à l'honneur de St Joseph

Quam felices Christi parentes, et quam amabiles! Joseph Jesum colit, Maria amplectitur. Jesus summo cum amore eos diligit. O felicissimi Christi parentes, virginitatis defensores, lilia semper candentia.

Suppliciter expossimus

Salvari vestris precibus.

[How blest the parents of Christ, and how worthy of love! Joseph fostered Jesus; Mary cherished Him. Jesus loved them with all his heart. O most blessed parents of Christ, defenders of chastity, ever shining lilies!

Humbly do we beg that you

Would bring Salvation by your prayers.]

The text of number 35 is from an unknown source; however, the last two lines seem to be taken from a metric hymn which I have not yet been able to identify. The text would suggest, as so many of the Québec motet texts do, that this motet was used not only for Feasts of St Joseph, but could also have been sung at Christmas, for the Feast of the Holy Family, and on many other occasions. This one motet can serve to demonstrate the musical qualities found in all four pieces of the group (example 1). The melody of "Quam felices" is Aeolian, and its frequent cadences emphasise the Aeolian tonic, mediant, and dominant; in addition, there are two lesser cadences on d. The music, following the sense and syntax of the text, divides into five sections that are roughly equal in length. Measures 1-12 set the first sentence "Quam felices Christi parentes, et quam amabiles!" and phrases and single words are repeated two or three times for emphasis. In the first five bars the tonal centre is clearly presented: the melody rises from $\mathrm{a}^{\prime}$ through $\mathrm{c}^{\prime \prime}$ to cadence on $\mathrm{e}^{\prime \prime}$, then gradually descends to cadence on $\mathrm{a}^{\prime}$. Starting at m. 6 , the melody rises dramatically to cadence on $\mathrm{a}^{\prime \prime}$, and then falls gently in a sequence to make an open-ended cadence on $\mathrm{e}^{\prime \prime}$. Measures 13-28 set the next two sentences, and the first of these, "Joseph Jesum colit, Maria amplectitur," is repeated more forcefully at $\mathrm{m}$. 19, continuing with the next sentence "Jesus summo cum amore eos diligit" in an animated eighth-note declamation. In mm. 29-43, "O felicissimi," with its quaestio notae figures (including diminished fourths), its repetition of melodic fragments in sequence, and its fall to low $\mathrm{e}^{\prime}$, builds in intensity as it approaches its cadence on $\mathrm{c}^{\prime \prime}$ in $\mathrm{m}$. 43. Measures 44-53 set the remaining two lines, which are poetic, in a manner reminiscent of Henry Du Mont's settings of St Bernard's Jubilus Rhythmicus (numbers 18, 19, 29, and 33 of his 1681 collection of Motets). The opening of Du Mont's Nil canitur suavius is shown in example 2. Like Du Mont, the anonymous composer of "Quam felices" uses flowing eighth-note motion, melodic sequences, and many surprising changes of direction. The Alleluia (mm. 54-65) forms the last section of the motet, and confirms the tonal centre with points of arrival on $e^{\prime \prime}, c^{\prime \prime}, e^{\prime}$, and $a^{\prime}$. The entire motet closes with a splendid melodic flourish. 

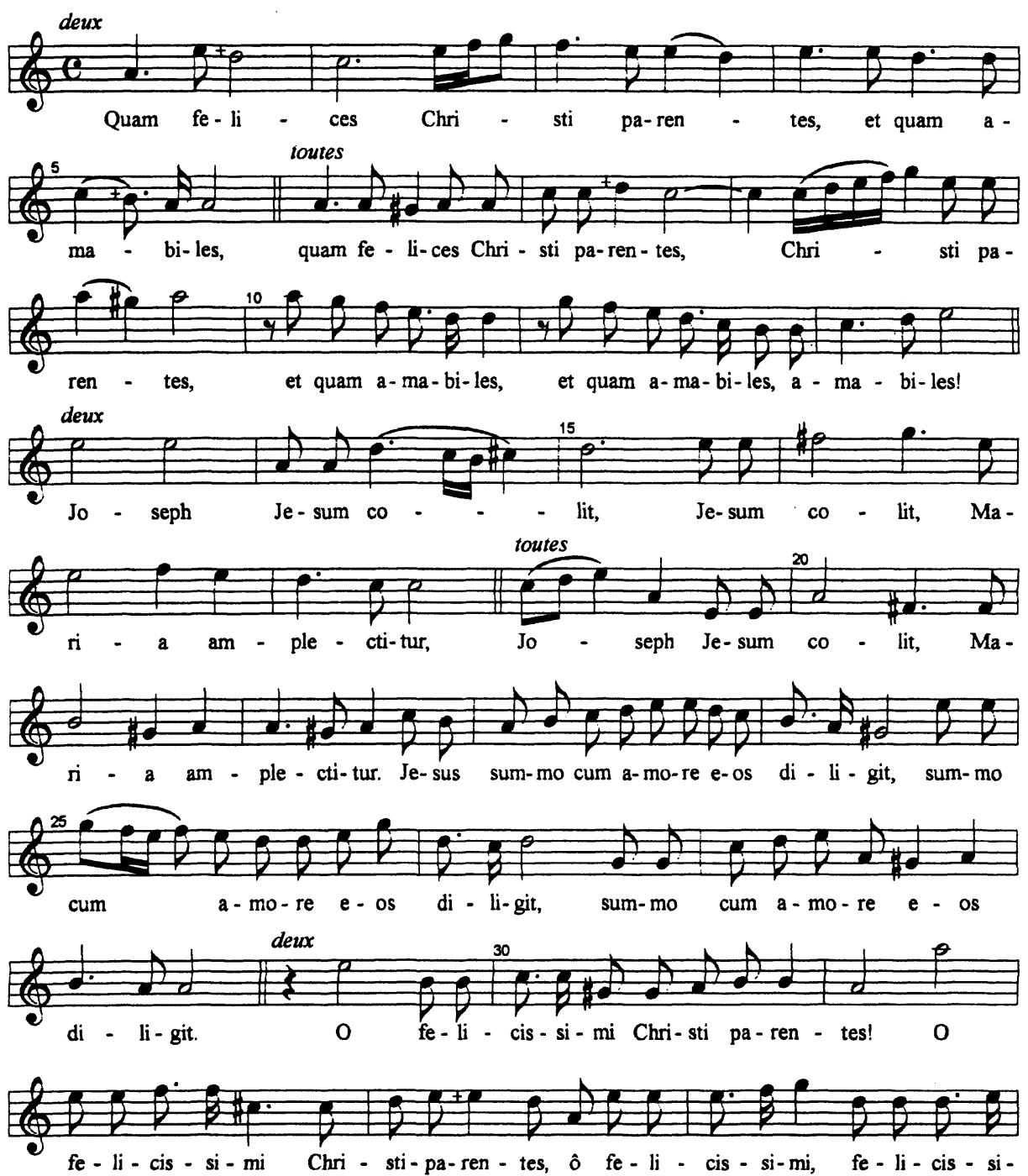

Example 1: Motet 35 (complete). 

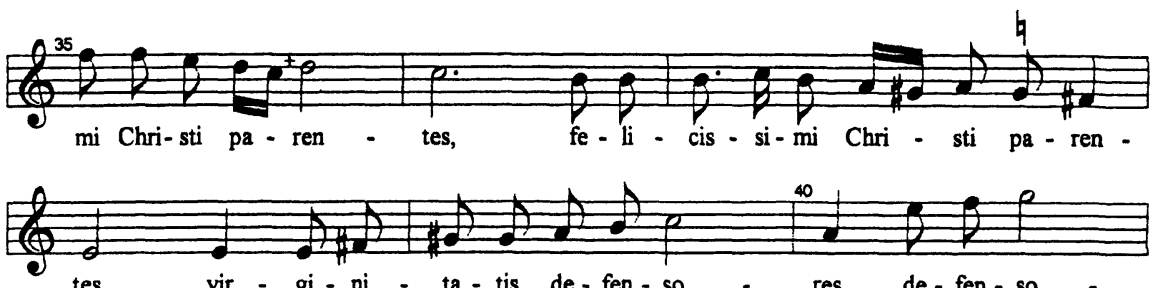

tes, vir - gi - ni - ta - tis de - fen - so - res, de - fen - so -

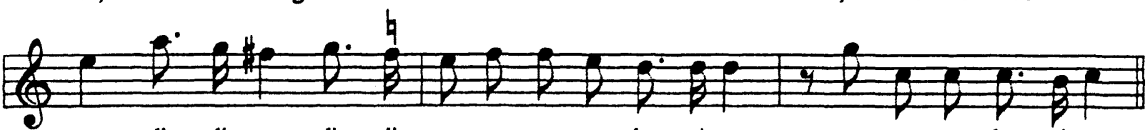

res, $\quad \mathrm{i}-\mathrm{li}-\mathrm{a}, \mathrm{li}-\mathrm{li}-\mathrm{a}$ sem-per can-den-ti-a, sem-per can-den-ti-a.

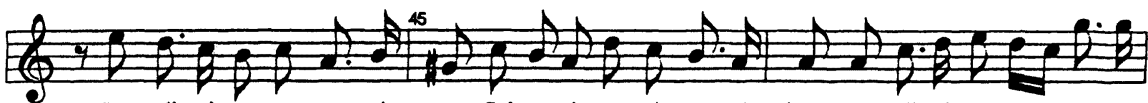

Sup-pli-ci-ter ex-pos-si - mus, Sal-va-ri ves-tris pre-ci - bus, Sup-pli-ci-ter ex - pos-si-
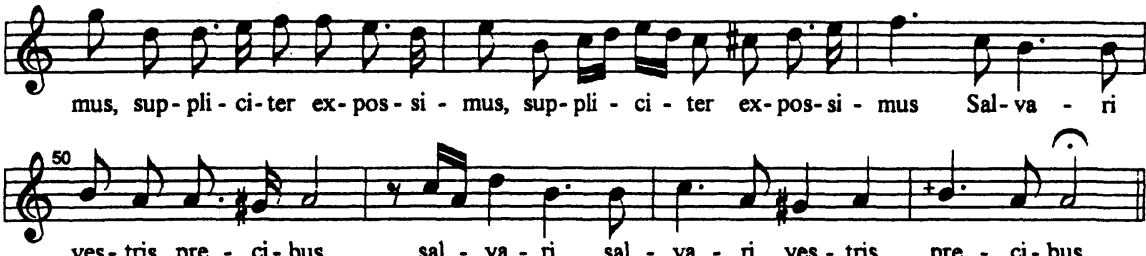

ves-tris pre - ci-bus, sal-va - ri, sal - va - i ves - tris pre - ci-bus.
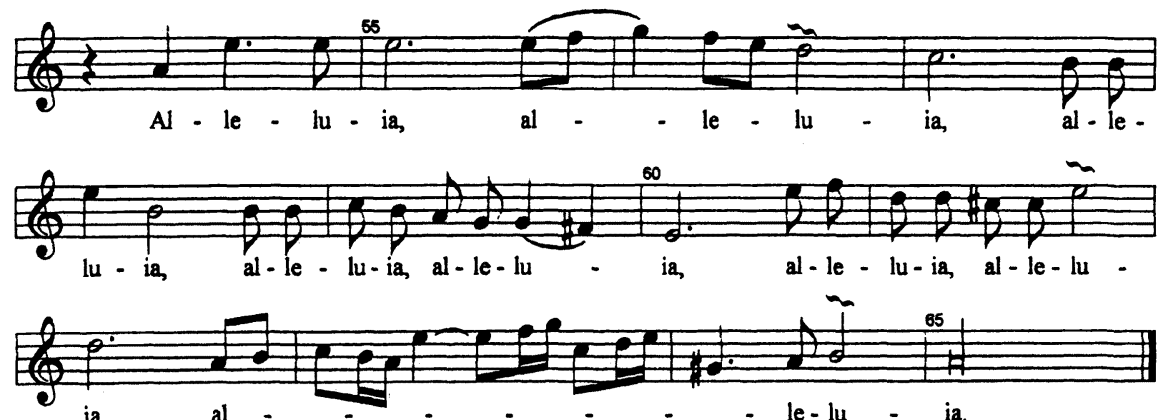

ia,

Example 1 (cont'd)

No. 36 (C xx) Autre Motet à l'Honneur de St Joseph

Joseph fili David, noli timere accipere Mariam conjugem tuam; quod enim in ea natum est, de Spiritu sancto est. Pariet autem filium: et vocabis nomen ejus Jesum: ipse enim salvum faciet populum suum [a peccatis eorum.]

[Joseph, son of David, do not be afraid to take thy wife Mary to thyself, for it is by power of the Holy Ghost that she has conceived this child; and she will bear a son whom thou shalt call Jesus, for he is to save his people [from their sins.]] 


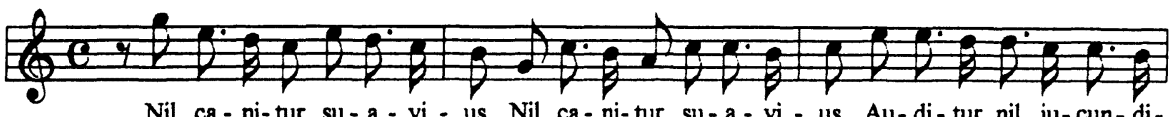

Nil ca-ni-tur su-a-vi - us, Nil ca-ni-tur su-a-vi - us, Au-di-tur nil ju-cun-di-

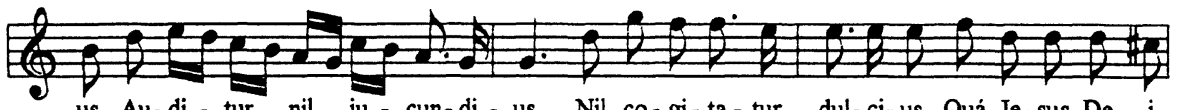

us, Au-di - tur nil ju-cun-di - us, Nil co-gi-ta-tur, dul-ci-us, Quá Je-sus De - i

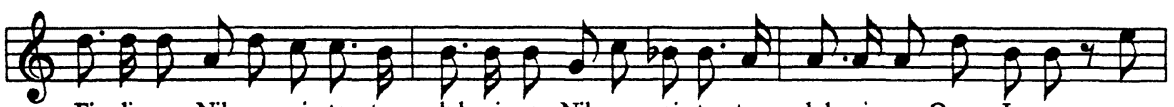

Fi-li-us. Nil co-gi-ta-tur dul-ci-us, Nil co-gi-ta-tur dul-ci-us, Quam Je-sus quam
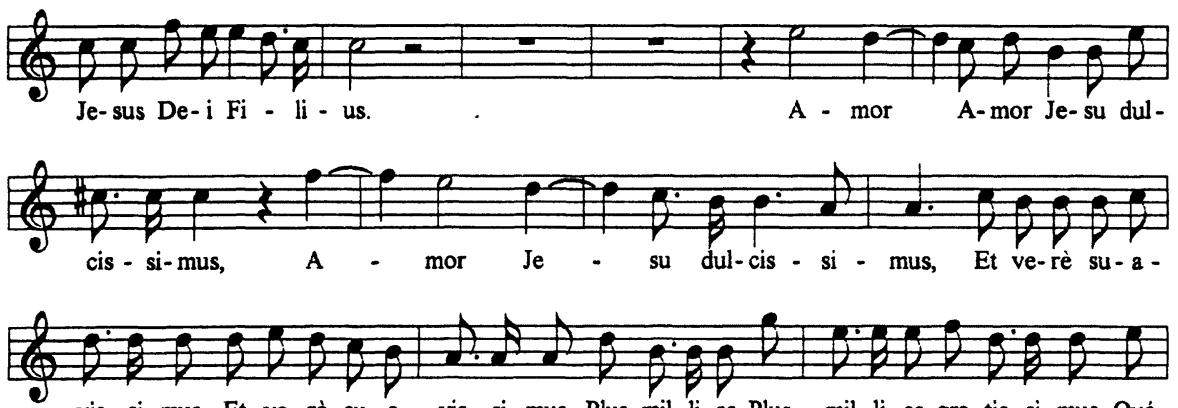

vis-si-mus, Et ve-rè su-a - vis-si-mus, Plus mil-li-es Plus mil-li-es gra-tis-si-mus Quá

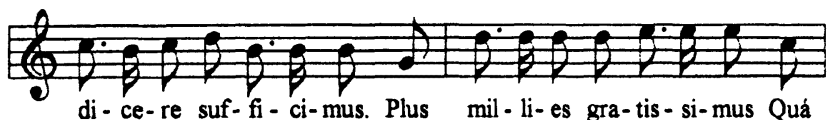

Example 2: Du Mont, "Nil canitur suavius” (beginning).

The text of number 36 is from the Gospel of Matthew 1:20-21. This text is used for a Respond at Matins of the Solemnity of St Joseph. In New France, the first part of the text was used as the Antiphon at the Magnificat on the Feast of the Holy Family. ${ }^{13}$ The first part also serves as the Communion Antiphon for the Feast of St Joseph, and as the Antiphon at the Benedictus of the Solemnity of St Joseph. Number 36 is in two sections that are almost equal in length, approximately 20 measures each. Both sections cadence in the Dorian tonic, and both are punctuated by cadences on the Dorian dominant. (The first 14 measures are shown in example 3.) The melody of number 36 , like that of number 35 , must be regarded as an example of careful musical craftsmanship: not only is the melody purposeful and controlled, it also shows the composer's attention to detail when setting words to music.

13For a facsimile of this Antiphon in the beautiful hand of Mère Marie-Andrée Duplessis de Ste-Hélène, see Willy Amtmann, La musique au Québec (Montréal: Les Éditions de l'Homme, 1976), 157. 


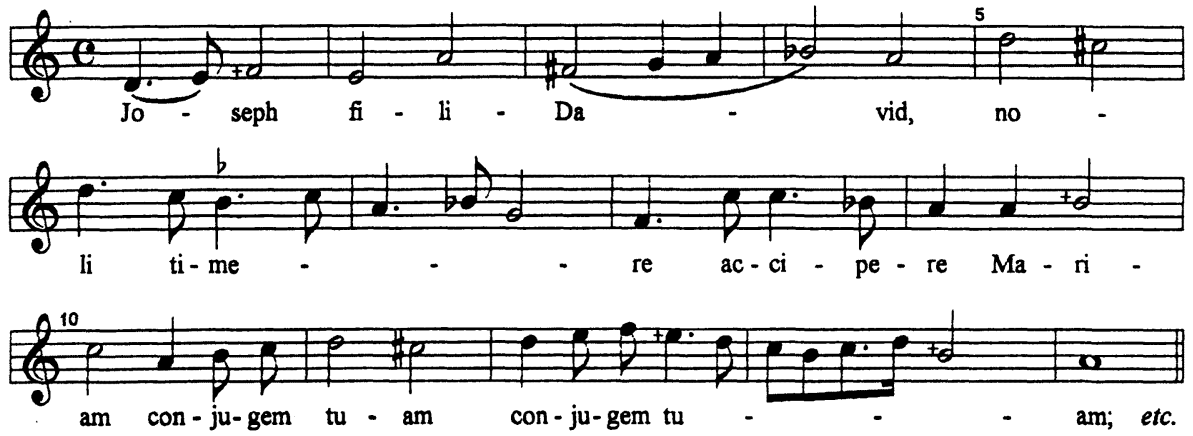

Example 3: Motet 36 (beginning).

\section{No. 36 (C xxiii-xxiv)}

[Ave Joseph, gratia plena; Dominus tecum:] benedictus tu in hominibus et benedictus fructus ventris sponsae tuae Jesus. Sancte Joseph, sponse Mariae Virginis, et pater nutritiae Jesu, ora pro nobis famulabus tuis, tuamque familiam continua protectione custodi.

[[Hail Joseph, full of grace, the Lord is with thee:] blessed art thou amongst men, and blessed is the fruit of thy spouse's womb, Jesus. Holy Joseph, husband of the Virgin Mary, and Foster Father of Jesus, pray for us thy servants, and keep thy family under thy continuous protection.]

The text of number 37, which is incomplete because of a missing page in the manuscript, is a paraphrase of the Angelic Salutation in the Gospel of Luke 1:28, 42: "Hail Mary, full of grace." "Ave Joseph" was a favourite prayer at the Ursulines' Convent, for it is mentioned many times, and quite fondly, in their annals. ${ }^{14}$ The motet, of course, has no particular liturgical function, but it could have been sung as a bénédiction or as a devotional piece. Number 37 is transposed Dorian, and like numbers 35 and 36, its tonal centre is immediately defined (in this case perhaps, redefined, for the beginning of the motet is wanting) by a descent from dominant to mediant to a cadence on the tonic in mm. 6-10 (example 4). The motet may have had a plainchant-style intonation, or its beginning may have been similar to what I have supplied in brackets. "Ave Joseph" is in three sections, corresponding to the syntax of the text: 1-16, with a cadence on the Dorian tonic; 17-29, with a Phrygian cadence on the dominant; and 30-43, with a cadence on the tonic. The two voice writing serves to emphasise the major text-divisions, and the harmony is effectively varied to sustain the melodic ideas. 

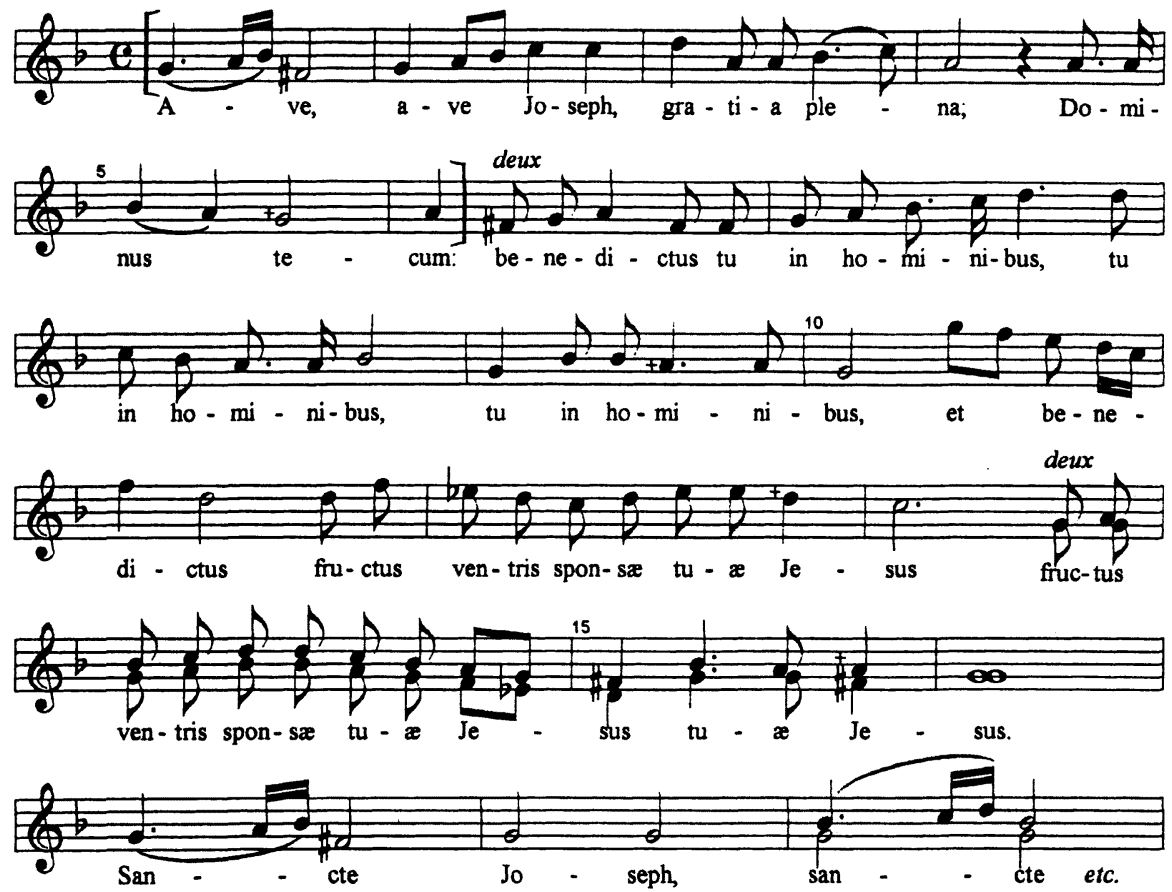

Example 4: Motet 37 (beginning).

No. 38 (C xxiv) Autre Motet à St Joseph

Fidelis servus et prudens, quem constituit Dominus suae Matris solatium, suae carnis nutritium, et solum in terris magni Consilii coadjutorem fidelissimum.

[O faithful and prudent servant whom the Lord appointed to be a comforter to His own Mother, a Foster Father to His own Son, and, alone on earth, a most faithful co-worker of the wonderful Counsellor.]

The text of number 38 is drawn from the second sermon on the text "Missus est angelus Gabriel" (Luke 1:26 ff.) by St Bernard of Clairvaux. Three passages from this sermon are used as lessons at Matins during the Octave of the Solemnity of St Joseph. St Bernard's text, a paraphrase of Matthew 24:25, may itself be a disguised quotation from one of his own poems, for the text begins with four eight-syllable lines. In the manuscript barlines are used only to mark the end of each verse. The pairs of melodic phrases: $\mathrm{aa}, \mathrm{bb}$, and $\mathrm{cc}^{\prime}$ are reminiscent of some of the simpler mediaeval 
hymns. ${ }^{15}$ The piece is in transposed Dorian, and like many plainchant hymns, the tonal centre is immediately announced by a leap of a fifth. The open-ended cadences of the first two phrases are answered by two phrases cadencing on the mediant. In the next last phrase there is a cadence on the supertonic, and the sixth phrase is extended to make a really forceful cadence on the tonic. The motet could well have been sung in free chant-like rhythm, or in a well-marked triple metre as the beginning suggests; however, there is no metre-signature in the source, and there are no rests (example 5). ${ }^{16}$

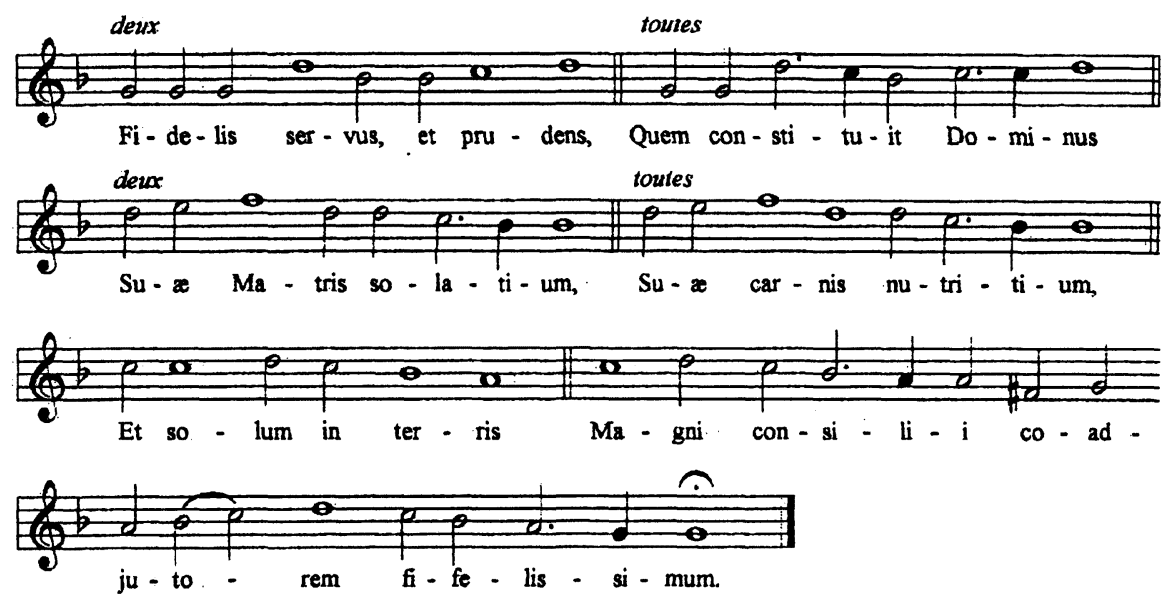

Example 5: Motet 38 (complete).

This group of motets, numbers $35-38$, is unified in style, modal treatment, and melodic gesture. The rest of the St Joseph motets, numbers $76,86,87$, and 108 , while not grouped together, also have features in common. While the first group all seem to be late seventeenth-century pieces, the second group appear to be eighteenth-century pieces: they all use triple metre (numbers 76 and 108 mix in some duple metre); they all have florid passages in running eighth notes; and they are all tonally conceived.

No. 76 (M1 115) Pour St Joseph

O Joseph, sponse virgo Virginis Mariae: te colant, te laudent, te celebrent omnes fideles. Josephum laudemus, celebremus, colamus, amemus. $O$ lux novae legis, Christi pater et custos: fulgebis in aeternum in domo Domini.

[O Joseph, chaste spouse of the Virgin Mary, all the faithful do honour you; they praise and extol you! Let us also praise, extol, honour, and love Joseph. 
O light of the new Covenant, Christ's father and guardian: may you shine forth forever in the house of the Lord.]

The text of number 76 is from an unknown source. The text has three sections, marked by periods, and a change from third person plural to first person in the verbs ("laudent"/"laudemus") personalizes the text and makes a point of the textual division. The third section ends with a "tag": "fulgebis in aeternum in domo Domini," a phrase which also appears at the end of number 87. Notable features of the music of number 76 are the clear $\mathrm{C}$ major tonality; a modulation to the dominant almost halfway through the piece; the changes of tempo: gravement, très vite, gravement, and gay; and the return of the two-voice section to end the piece (example 6).

No. 86 (M1 180-82) Pour St Joseph.

Exsultent superi,

Laetentur homines:

Et Josephi solemnia,

Et laudes et praeconia

Devotis mentibus,

Laetis concentibus

Resonant in Ecclesia.

[May the heavens exult and may mankind rejoice with devout minds and with joyful strains; and at the Solemnity of Joseph may his praises and acclaim resound in the Church.]

Number 86 is adapted from Nicolas Bernier's first book of Mottets (1703). Bernier's text is paraliturgical, and its easy "neo-Latin" poetry is the work of Pierre Portes. ${ }^{17}$ Bernier's motet is in several movements, and the first movement "Exsultent superi"-by itself an ABA form-is repeated to close the motet. The version of the Ursulines, number 86 , is an arrangement of the first movement for voice alone, and although the $d a$ capo is not indicated, the opening thirteen measures should probably return to end the little motet. The anonymous adapter has made a few changes to her model: $\mathrm{mm}$. 7-13 have been recomposed because the adapter wanted a slightly shorter A section. She has omitted the basse continue, which in the original provided a prelude and a two-measure interlude after the motto beginning (example 7). ${ }^{18}$

17 The text of "Exsultent superi" is printed in Pierre Portes's Cantiques pour les principales festes de l'année ... (Paris: Jean Guignard, 1685), 88. See Jean Duron, "Marc-Antoine Charpentier: Mors Saülis et Jonathae-David et Jonathas, de l'histoire sacrée à l'opéra biblique," Revue de musicologie 77, no. 2 (1991), 262-68, for an alphabetical list of Portes's Latin poetry. Two additional texts from the Québec repertoire: "O Triumphantis Jerusalem" and "Ornate Aras" are also by Portes.

18For information about the process of adapting pieces for the limited resources of New France, see Erich Schwandt, "Le motet classique français en nouvelle France: cent années d'adaptation (1652-1755)," in Actes du colloque international de musicologie sur le grand motet français (1663-1792), ed. Jean Mongrédien (Paris: Presses de l'université de Paris, 1986), 199-213. 

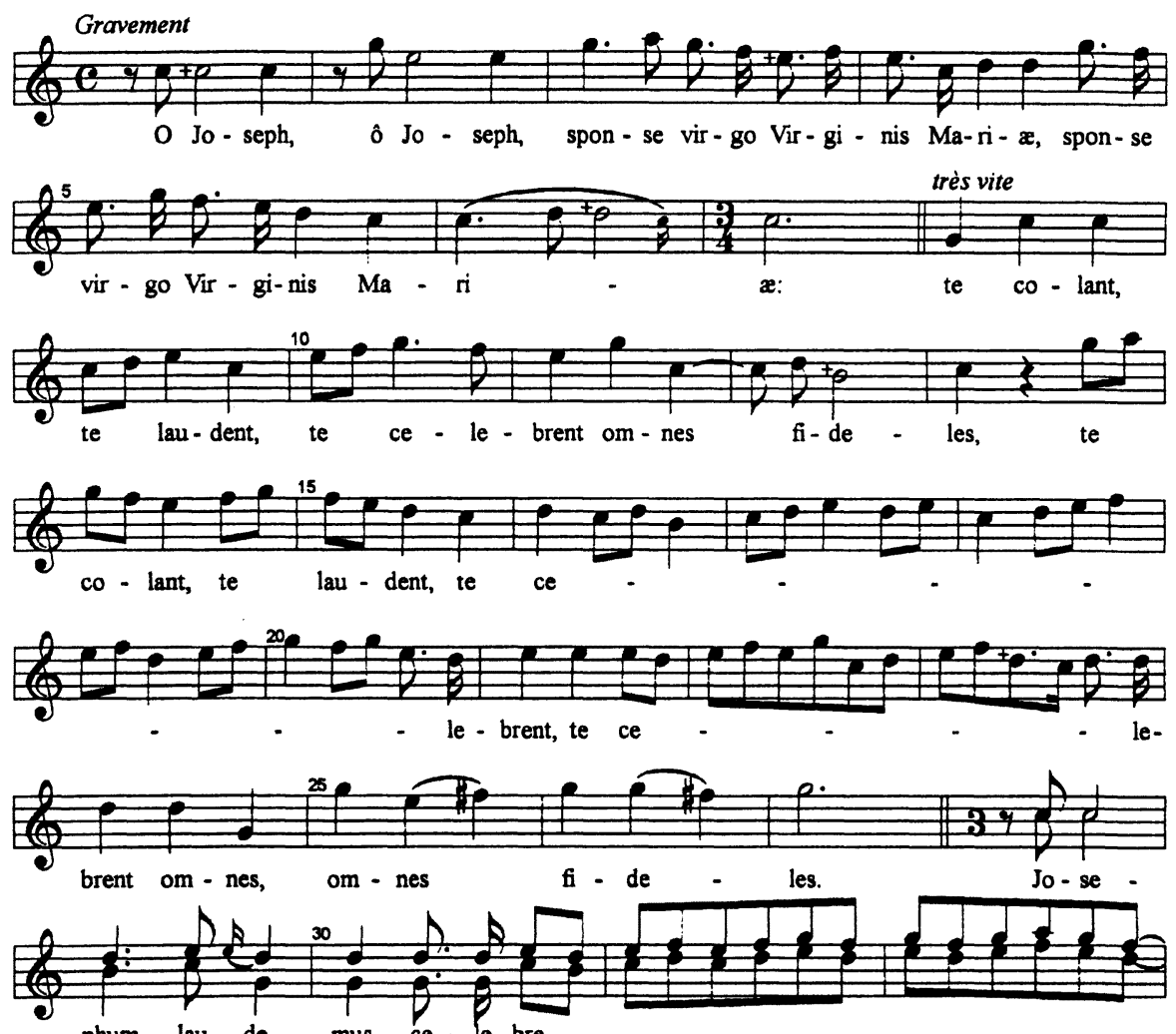
phum lau - de - mus, ce - le-bre
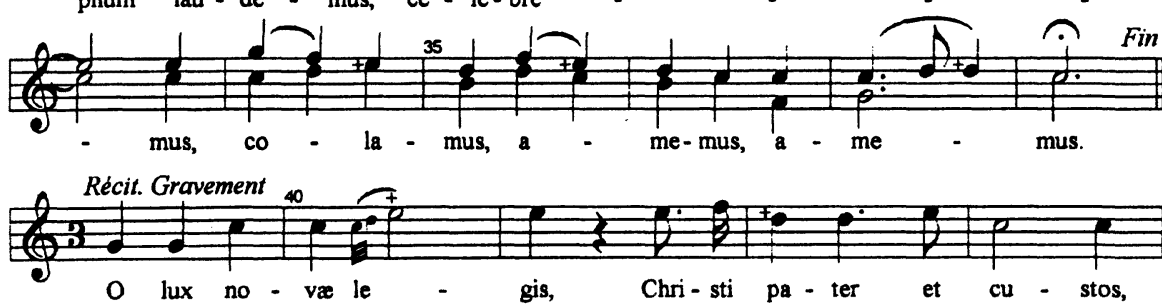

Example 6: Motet 76 (complete). 

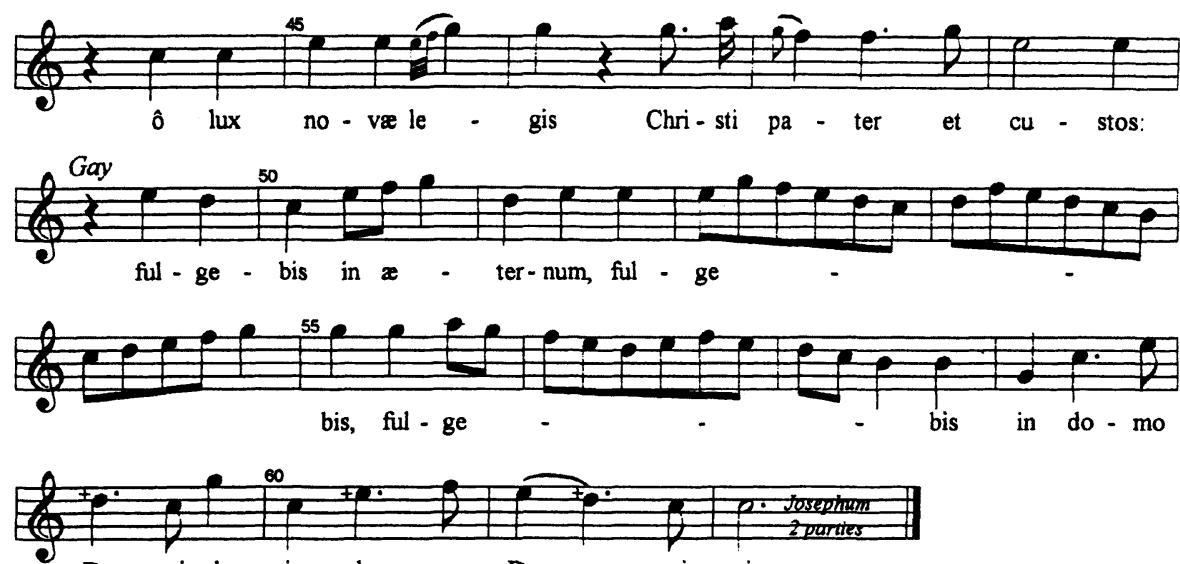

Do - mi-ni, in do - mo Do - mi - ni.

\section{Example 6 (cont'd)}

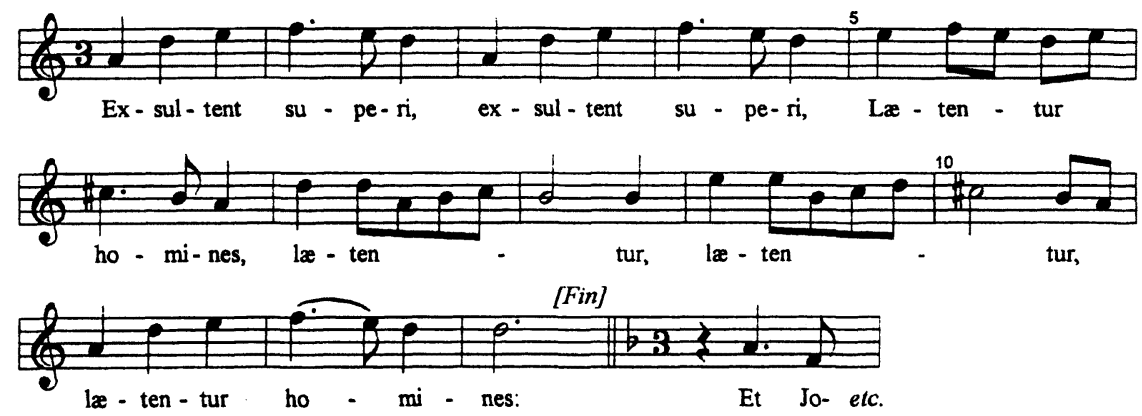

Example 7: Motet 86 (beginning).

No. 87 (M1 182-84) Autre pour St Joseph

Joseph, vir Mariae, vir electus ex millibus: pueri Jesu nutritius et custos fidelissimus: fulgebis in perpetuum in domo Domini.

[O Joseph, Mary's spouse, a man chosen from a thousand! O Foster Father of the child Jesus, and most faithful guardian: may you shine forth forever in the house of the Lord.]

The text of number 87 is from an unknown source. It shares its closing "tag" with number 76. This short motet is in C major, and like number 76, there is a modulation to the dominant about halfway through the piece. Everything is on a small scale, and the running eighth-note passages are restricted to two measures only, measures 19 and 21. Again the syntax of the text helps to shape the melodic line. (The piece is given complete in example 8.) 

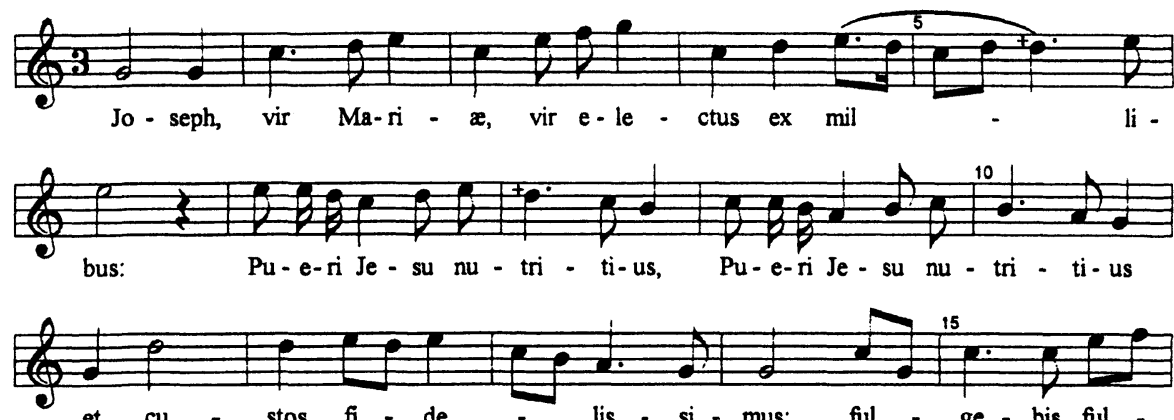

et cu - stos fi - de - lis - si - mus: ful - ge - bis, ful -
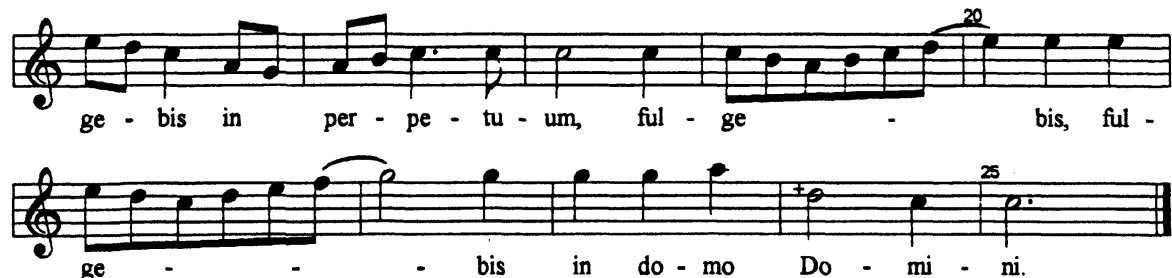

Example 8: Motet 87 (complete).

No. 108 (M1 259-63) Autre Motet pour St Joseph

Exsultent superi, etc. (The text is identical with that of No. 86.)

The text of number 108 is taken directly from the Motet pour St Joseph, number 86 . The anonymous composer has taken the arrangement of Bernier's motet as her model, and has composed a new motet, which has a change of metre and a change of tonal centre for the middle portion of the piece. She has dropped the da capo idea of Bernier's original-the da capo is not clearly indicated in number 86-in favour of a brilliant ending. The odd cadence-formulas of measures 5,9, and 16 suggest that the piece was meant to be a two-voice piece, with the second part following the notated part at the interval of a third or sixth. It would be easy enough to improvise such a part, and the odd cadence-formulas would be much improved. (The first 21 measures are given in example 9.) The third section (mm. 41-66) is quite satisfactory as one-voice music: it could be sung as a solo or with several voices in unison.

In conclusion, the two groups of St Joseph motets from the Archives of the Ursulines are quite distinctive in style. The first group (35-38) are late seventeenth-century pieces of high musical quality which were copied out together in the early eighteenth century. The four pieces are all modal in their melodic construction, all have texts that are scriptural or which imitate scripture, and in all four, music and text are carefully co-ordinated. 

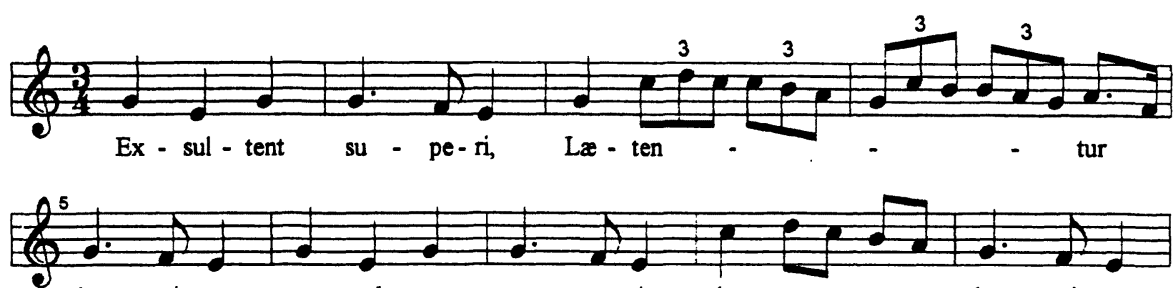

ho - mi-nes, ex - sul-tent su - pe-ri, læ - ten - tur ho - mi-nes,
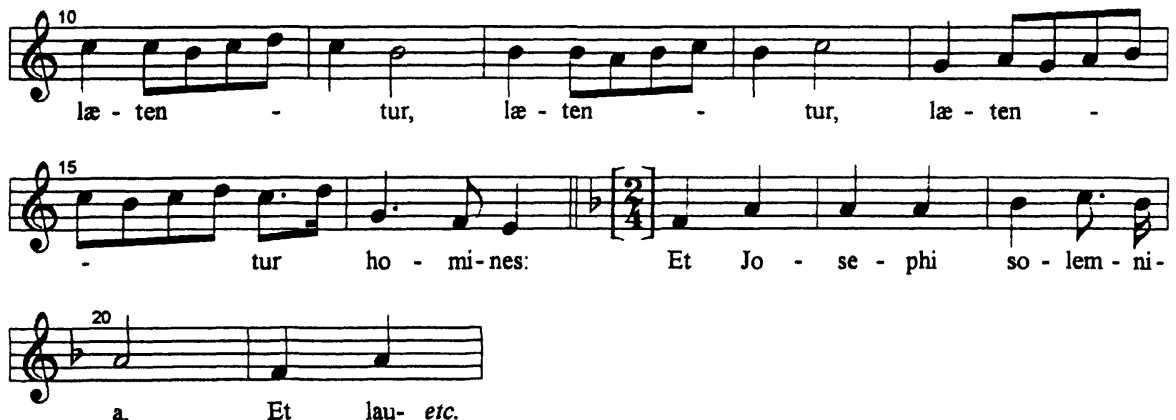

Example 9: Motet 108 (beginning).

The second group (76, 86, 87, and 108) were obviously composed in the eighteenth century since they exhibit many features of the "classic" French motet style made popular by Campra, Bernier, and Morin. They are all tonally conceived, their texts are paraliturgical, and they all use triple metre with running eighth-note passages-a prominent feature of the eighteenth-century motet.

On the basis of this evidence, it can be shown conclusively that Père René Ménard can have had no hand in the composition of any of the St Joseph repertoire preserved at the Archives of the Ursulines of Québec.

\footnotetext{
Abstract

There is a handful of motets in honour of one of New France's most important patrons-St Joseph-preserved at the Archives of the Ursulines of Québec. This group of eight motets has formed the basis of speculation about the musical gifts of Père René Ménard and Mère Marie de St Joseph. Both of them are mentioned in 1640 as being capable musicians, but both were dead by the middle of the seventeenth century. In this article the St Joseph motets are examined to see if there is any basis for connecting any of the music to either person. Unfortunately, all of the music is stylistically much too late to have been composed by Père Ménard, or to have been assembled or copied by Mère de St Joseph. Solum nomen super est.
} 